\title{
The Dependence of the Palestinian political Elite on Social Media Networks and their applications as a Source of information about the Deal of the Century
}

\author{
Dr. Amin Mansour Wafi* \\ "Associate Professor of press and Media" \&Head of the Department of Press and Media at the Islamic \\ University of Gaza
}

*Corresponding Author: Dr. Amin Mansour Wafi, "Associate Professor of press and Media" \&Head of the Department of Press and Media at the Islamic University of Gaza

\begin{abstract}
The study aims to identify the dependence of the Palestinian political elites on social media networks and their applications as a source of information about the Deal of the Century. It is a descriptive study that used the media survey approach, and the sheet tool as a basic tool for the study. The study population came from the political elites, faction leaders, political analysts, academics in the Political science, journalism and media department, and the current and former Legislative Council deputies. The available sample selected reached 123 members of society. The study reached a set of results, the most important of which are: 60.5\% depend on social media networks and their applications as a source of information about the Deal of the Century. WhatsApp ranked first, and then Facebook network second from among the networks that were relied upon. Further, the results showed that cognitive effects came first, emotional influences second and behavioral effects third. One of the most important recommendations of the study is to pay attention to information sources, and not to publish or provide anonymous news and information.
\end{abstract}

Keywords: the political elite - social networks and their applications - dependency - information sources the Deal of the Century.

\section{INTRODUCTION}

Social media networks and their applications have become an important source of news and information. They compete with traditional media through the characteristics, functions and capabilities due to their ability to keep pace with modern technology that has accompanied man in the various fields of his life. For example, actually, the cell phone has become a companion to man in all his movements and presence. With the availability of aerial communication networks and the ease of access to Internet through these devices, making the capabilities of all media available through phones and modern devices all this increased the control and spread of modern media at the expense of traditional media.

People are no longer able to differentiate between social networks and applications that operate in the same communication framework and the virtual world in which we live, as most networks have applications, and the applications have networks. Thus, separating them is not easy, but the combination in many cases is better. This may be due to the processes of mergers, integration and compatibility in the content and the communication systems through which the work is carried out.

The technological challenges that we live in, the digital world, imposed on us to keep pace and use. This is shown by what we see today of the acceleration and competition in possessing the tools of technology hoping to occupy a social position that guarantees for us elitism within our societies. Any community elite, if it is not able to keep up and follow up, will not be able to play its role in light of the spread of information, the spread of the citizen's journalistic time, which the digital revolution has allowed him to send and receive a large amount of information and news and change the rules of traditional media work known to him.

It may be appropriate for the elites, especially the political elite in our societies, to arm themselves with all technological capabilities to carry out the societal roles entrusted to them, especially in light of the different social conditions that have characterized modern societies. The political elites have 
become in need of diversity in their media sources and diversity in their information in order to carry out the tasks assigned to them by society.

With regard to the Palestinian society, which is characterized by rapid political fluctuations and regional and international changes that affect the Palestinian cause, the challenges are increasing, especially with the liquidation processes that the Palestinian cause is going through; the latest of which was US President Donald Trump's vision for a political settlement in the Arab region, or the socalled "Deal of the Century". A settlement project has become evident, which the Palestinian leadership and factions must respond to the American calls for a solution and an end to the ZionistArab conflict according to the American vision.

This study came to identify the extent of Palestinian political elites' dependence on social media networks and their applications as a source of information and news about the Deal of the Century, the most important networks and applications that the political elite relies on, knowing the degree of trust and credibility in them, the most important effects resulting from the adoption and the most important problems, solutions and proposals.

\section{The first topic: the Methodological Procedures of the Study.}

\section{First: Previous studies}

The study of Al-Shalhoub (2020 AD) ${ }^{1}$ showed: the motives that drive the Saudi public to dependon social media sites for knowledge of Saudi society issues. This study falls within the descriptive research that used the survey studies method, within its framework, the method of surveying the masses of the mass media, the survey tool and relied on Media Dependence Theory. One of its most important results is the audience's dependence on Twitter with a very large degree of knowledge of Saudi society issues with an average of (4.44), and then WhatsApp with an average of (3.50). The study of Mudhih (2019 AD) ${ }^{2}$ showed: which aimed to identify the extent of the elite's dependence on social media sites in crises. It is a descriptive study that used the survey method, and within its framework the method of surveying the media audience, the study data were collected through the interview and survey tool, which was distributed to a random sample. The study was based on the theory of dependence. One of the main reasons for the elite's dependence on social media is understanding and guidance. The elite ensured that the role of mobilization and guidance with causing confusion among citizens and contributed to spreading rumors during the crisis. Nassar's study $(2017)^{3}$ showed the reliability of the information provided by news pages on social media, the elite's attitudes towards it and the extent of their dependence on these sites. It is a descriptive study and it used the survey method, and within its framework the two methods of content analysis and mass media survey. Study data were collected by means of a content analysis form. The study was based on the theory of media dependence. Among its most important results is that there is a positive statistically significant relationship between the degree of dependence on news pages on social media and the total practices on news pages on social networking sites. The Sarafandi study (2017 $\mathrm{AD})^{4}$ aimed to identify the attitude of political and media elites towards the Palestinian diplomatic performance from 1993 until 2016 AD. It is a descriptive study that used the survey studies method. Within its method of surveying media audiences, the study data was collected through the survey sheet tool, and a stratified sample of politics and media professors was chosen. The study was based on the theory of dependence on the media, and among its most important results $82.8 \%$ of the respondents found that the split had a direct impact on the Palestinian diplomatic work. Al-Masry's study (2016) ${ }^{5}$ came to identify the role of the Palestinian media elite in using social media sites to market the Palestinian cause. This study falls within the descriptive research that used the survey studies approach. Within its framework is the method of surveying media audiences. It used the survey tool and adopted the theory of media dependence. Among its most important results, the crimes of the Zionist occupation came first with regard to the issues of the topics discussed on social 
media, from the viewpoint of the media elite, by $85.5 \%$.The study of Al-Batsh (2016) ${ }^{6}$ showed the evaluation of political and media elites on "Palestinian media discourse towards the issue of the siege of Gaza." This study falls within the descriptive research that used the survey studies approach. Within its framework is the method of surveying media audiences. It relied on the theory of media dependence. Among its most important results, the political and media elites strongly support that the division is one of the internal obstacles affecting the Palestinian media discourse towards the issue of the siege.Al-Azzam's study $(2015)^{7}$ showed the extent to which the Jordanian elites depend on talk shows provided by Al-Jazeera as a source of political information. It is a descriptive study. Survey studies methodology was used. Within its framework is the method of surveying media audiences. Data were collected through the survey sheet tool. The study was based on the theory of media dependence. Among its most important results is the dependence of the Jordanian elites on the talk shows on Al-Jazeera and following up on political developments in Iraq's status quo then, the political developments of the Palestinian cause and the Arab-Israeli conflict. Ognyanova \& Ball-Rokeach $(2015)^{8}$ demonstrated the extent to which dependence on the Internet affects political effectiveness and how new media affects people's confidence in the political process. This study falls within the descriptive researches that used the survey studies method and within its framework the method of surveying the media audience. The study was based on the theory of media dependence. Among the most important results there is a positive correlation between dependence on the Internet and the political orientations of the respondent. Khalifa (2014) study ${ }^{9}$ showed the extent to which students of Jordanian public universities depend on news websites to seek information about political issues. It is a descriptive study. Survey studies approach was used. Within its framework is a survey of media audiences. Data were collected through the survey sheet tool. The study was based on the theory of media dependence. Among its most important results, the three universities' students under study depend on Jordanian news sites in forming their political awareness, as it came in a large percentage.

Defining the problem of the study: The problem of the study lies in identifying the extent to which the Palestinian political elite depends on social networks as a source of information about the deal of the century announced by the US President as a framework for solving the Palestinian cause, through knowing the patterns of follow-up, the degree of interest and confidence in the communication networks and their applications, knowing the cognitive, emotional and behavioral effects attainment of the political elite as a result of this dependence.

\section{The importance of the study}

1. The importance of the study comes from the importance of the Palestinian political elite, as the elites are among the most influential actors in the local and international public opinion.

2- The importance of social media networks and their applications, which have become an easy-touse media source, especially in light of the great technological development in the means of communication.

3- It provides an idea about the uses and employment of communication networks, their applications in the process of transferring information, news, reliance on it and its exchange between members of societies.

4- This study is an academic product to be added to the Palestinian Media Library in the field of media and political studies.

\section{The study's Objectives\& Questions:}

The objectives of the study can be formulated in a major goal, which is the extent to which the Palestinian political elites depend on social networks and their applications regarding the Deal of the Century announced by the US President as a framework for a solution to the Palestinian cause, and it includes the following sub-questions: 
1. What is the degree of the Palestinian political elite's dependence on social media networks and their applications as a source of information about the Deal of the Century?

2. What are the forms of the Palestinian political elite's follow-up on social media networks and their applications as a source of information about the Deal of the Century?

3. What are the most important social networks and their applications that the Palestinian political elite relied on as a source of information about the Deal of the Century?

4. What are the reasons for the Palestinian political elite's dependence on social media networks and their applications as a source of information about the Deal of the Century?

5. What is the degree of Palestinian political elite confidence in the content of social networks and their applications as a source of information about the Deal of the Century?

6. What are the cognitive, emotional and behavioral impacts resulting from deepending on social networks and their applications as a source of information about the Deal of the Century?

7. What are the most important problems and proposals related to social networks and their applications as a source of information about the Deal of the Century?

Studv Theoretical Framework: The study is based on the literature of the theory of media dependence:

Where the individual's dependence on the media is considered one of the important theories that dealt with media content and the public. This is formulated through the theory of the interdependence between the media, social systems and the audience that deals with these medias ${ }^{10}$. This theory is concerned with monitoring the different influences of the media on the individual and society. Media dependence is an environmental theory which views society as an organic structure. From this standpoint, it tries to give clear explanations about the effects of the media by answering many questions including: Why do the media sometimes have strong direct effects and other times, indirect and somewhat weak effects. To answer these questions and to explain the totality of these interconnected relationships that are sometimes complex and have different effects at other times because it is also not possible to study the relationship between the media, society and individuals in a theoretical vacuum, without relying on explanatory theoretical models, especially if it comes to researching the effects of media, which is one of the thorny and difficult studies. The founders of the theory of "dependence" (Melvin Devler and Sandra Paul Rocketch) relied on the main issues that preceded the theoretical representations that preceded them, including: the interest of functional construction in social stability, the changing focus of the conflict ideal, the emphasis on the social adaptation of the evolutionary example, the focus on the creation of meanings In the symbolic interactive perspective, the interpretation of individual factors (emotions, values, attitudes, and behavior) from the perceptual model ${ }^{11}$

Tvpe of study: This study belongs to descriptive studies that aim to characterize and analyze the phenomenon in its current situation, with the aim of reaching results and generalizations that help in understanding and developing reality ${ }^{12}$ The study aimed to describe the extent to which the Palestinian political elite relied on social networks as a source of information about the Deal of the Century as a framework for resolving the Palestinian issue.

\section{Studv Methodologv: one of the most appropriate approaches for this type of studies}

is the Media Survey Approach: This approach has been used due to its suitability for this type of studies, which is considered a structured scientific approach aimed at obtaining data, information and descriptions about a phenomenon or a group of phenomena, by surveying the mass media to identify the general characteristics and the basic features that distinguish the audience and his preferences $^{13}$ 
The Dependence of the Palestinian political Elite on Social Media Networks and their applications as a Source of information about the Deal of the Century

\section{Data collection tool:}

Survey sheet: The survey sheet was used for its convenience for this type of empirical study. The survey sheet is one of the primary methods of collecting information and data ${ }^{14}$. The investigation process consists in asking a group of pre-prepared questions that cover all aspects of the research problem. The investigation sheet was divided into the following axes

1- Characteristics of the study sample.

2- Forms for respondents to follow up on social networks and their applications.

3-Patterns of dependence on social networks and their application.

4-The degree of credibility and confidence in social media networks and their applications.

5- Types of effects of relying on social networks and their applications.

Personal interview: The researcher conducted an unregulated interview with the various political elites in order to get acquainted with their views on the information provided by social networks during the Deal of the Century. To take their point of view and evaluate them to develop the role that social networks play as a source of information during the Deal.

The personal interview includes inviting the respondent to the service site or the research office (it is called an individual interview). Sometimes the interviews take place at a person's workplace or at home ${ }^{15}$ and the personal interview sheet consists of a set of questions

Study population: we mean by the study community, the total vocabulary that we are trying to study to achieve the results of the study ${ }^{16}$. These vocabularies represent the target community that we aim to study. The researcher endeavored to define the study population in the following: the political elites represented by the leadership of the following Palestinian factions: the National Liberation Movement, Fatah, the Islamic Resistance Movement, Hamas, the Islamic Jihad Movement, the Popular Front and the Democratic Front. The researcher chose these factions because they represent the majority of the Palestinian people. These factions had an effective role during the activities against the Deal of the Century as well as the new and former representatives of the Legislative Council, (academics in the departments of political science, journalism and media) of Palestinian universities and political analysts. They are the ones who write political articles in Palestinian newspapers and publish their analyzes through various media outlets

The study sample: We mean by the sample of the study the category that has been chosen from the community for the study to be conducted on, as well as obtaining a sample that represents the community well. There is a basic rule that the greater the sample size, the less probability of standard error $^{17}$, based on that, the researcher approved the available sample from the community where the number of that sample reached 140 individuals. The survey sheet, the study tool, was distributed to them. 123 questionnaires were retrieved, equivalent to 87.9\%, which is an acceptable percentage for conducting the study and distributing the survey sheet.

\section{Sample characterization:}

Table No. (1). Shows the distribution of the respondents according to the gender variable

\begin{tabular}{|c|c|c|c|}
\hline Attribute & Attribute categories & The number & percentage $\%$ \\
\hline \multirow{3}{*}{ gender } & Male & 96 & 78.1 \\
\cline { 2 - 4 } & female & 27 & 21.9 \\
\cline { 2 - 4 } & total & 123 & 100.0 \\
\hline \multirow{3}{*}{ Attribute } & Attribute categories & 19 & the number \\
& academic & 37 & 30.1 \\
\cline { 2 - 4 } & A leader in a political faction & 41 & 33.3 \\
\cline { 2 - 4 } & Writer and political analyst & 15.5 \\
\hline
\end{tabular}


The Dependence of the Palestinian political Elite on Social Media Networks and their applications as a Source of information about the Deal of the Century

\begin{tabular}{|c|c|c|c|}
\hline \multirow{3}{*}{ work nature } & Deputy in the Legislative Council / current or former & 26 & 21.1 \\
\cline { 2 - 4 } & Total & 123 & 100.0 \\
\hline \multirow{3}{*}{ Attribute } & Attribute categories & the number & percentage \% \\
\cline { 2 - 4 } & 20 - less than 30 & 15 & 11.9 \\
\cline { 2 - 4 } & $30-$ less than 40 & 47 & 38.6 \\
\cline { 2 - 4 } & $40-$ less than 50 & 36 & 29.5 \\
\cline { 2 - 4 } & 50 years or more & 25 & 20.0 \\
\cline { 2 - 4 } & Totall & 123 & 100.0 \\
\hline
\end{tabular}

1. Gender: The percentage of the gender in which the study was conducted was as follows: The percentage of males in the study was $78.1 \%$ while the percentage of females was $21.9 \%$. Perhaps this is natural due to the nature of the research community as it is an elitist political society in which the percentage of males prevails over females.

2. Nature of work: It is clear from the table that $15.5 \%$ are academics. $30.1 \%$ are leaders of political action factions. $30.1 \%$ are writers and political analysts and $33.3 \%$ are members of the Legislative Council, elected in the Palestinian elections that were held in the areas of the National Authority in 1995 and 2006

3. Age: It is clear from the previous table that $11.9 \%$ of those whose ages range from 20 to less than 30 years old. $38.6 \%$ of those whose ages range from 30 to less than 40 years old and $29.5 \%$ are among those who their age ranges from 40 to less than 50 years and $20.0 \%$ are those 50 years and over.

\section{Validity and Stability Tests:}

\section{First: the validity test:}

The validity of the analysis means the validity of the measurement tool for what was developed to measure ${ }^{18}$ it and to test the validity of the study form. The apparent validity of the questionnaire was measured through. It was also presented to a group of faculty members in universities so that the researchers asked the referees to express their views on the appropriateness of the phrases to measure what they were put for the clarity of the wording of the phrases. The extent of the appropriateness of each statement to the axis to which it belongs and the adequacy of the phrases to cover each axis of the basic study variables, in addition to suggesting what they deem necessary in terms of modifying the wording of the phrases, deleting them or adding new phrases to the study tool. ${ }^{19}$

\section{Second: Stability Test:}

The consistency of the study tool is intended to ensure that the answer will be approximately the same if it is repeatedly applied to the same people at different times. The researcher performed stability steps on the exploratory sample by calculating several stability parameters, the most important of which are Cronbach's Alpha and Lambda coefficient, where the value of the Cronbach alpha coefficient was (0.831). It is a high value which indicates the validity of the study tool for application. The lambda factor was calculated to verify the first result (0.839). This result supports the validity of the study tool for application.

\section{The second topic: the results of the field study}

First: General Findings: This chapter presents the general results of the field study on the Palestinian political elite's dependence on social media networks and their applications as a source of information about the Deal of the Century. The field study was conducted on the available sample from the original community, where the number of that sample reached 150 individuals, which was distributed to the available sample for the study. The results of the study were as follows:

First: Habits and patterns of following social networks and their applications:

1. The degree of keenness to follow up on social media networks and their applications. Table No.

(2) Shows the degree of concern for following up on social media networks and their applications

\begin{tabular}{|l|l|l|l|l|l|l|l|l|}
\hline $\begin{array}{l}\text { Follow- } \\
\text { up }\end{array}$ & $\begin{array}{l}\text { very } \\
\text { high }\end{array}$ & High & Medium & Low & very low & SMA & $\begin{array}{l}\text { Relative } \\
\text { weight }\end{array}$ & $\begin{array}{l}\text { The probability } \\
\text { value }\end{array}$ \\
\cline { 1 - 3 } K & 37 & 45 & 34 & 5 & 2 & 3.89 & 77.80 & 0.000 \\
\hline$\%$ & 30.1 & 36.6 & 27.6 & 4.1 & 1.6 & & & \\
\hline
\end{tabular}


The Dependence of the Palestinian political Elite on Social Media Networks and their applications as a Source of information about the Deal of the Century

The arithmetic mean is statistically significant at a significance level of 0.05 . The results of the previous table indicate that $30.1 \%$ are very keen to follow social media networks as a source of information about the Deal of the Century. 36.6\% are those who keep a high degree, $27.6 \%$ are those who keep a moderate degree, $4.1 \%$ are those who keep a low degree, while $1.6 \%$ are those who keep a very low degree. In general, it was found that the relative weight is equal to $77.80 \%$ and the probability value is equal to 0.000 , which is less than the significance level 0.05 . This indicates the high approval of the degree of keenness to follow social networks and their applications as a source of information about the Deal of the Century. It is evident from the results that the degree of political elites' keenness to follow social networks and their applications was more than the average, so that a high degree topped the respondents' keenness scores with a very high difference. This clearly indicates the importance of social media networks, their applications, and their follow-up by the Palestinian political elite. Specifically about the deal of the century, as social networks and their applications were the fastest and easiest way to follow the event.

Follow-up volume of social networks and their applications:

Table No. (3). Shows the follow-up rate for social networks and their applications

\begin{tabular}{|c|c|c|}
\hline Follow-up rate & Repetition & percentage \% \\
\hline Daily & 74 & 60.2 \\
\hline Three or four days & 21 & 17.1 \\
\hline Five days or more & 18 & 14.6 \\
\hline A day or two & 10 & 8.1 \\
\hline total & 123 & 100.0 \\
\hline
\end{tabular}

The results of the previous table indicate that $60.2 \%$ of those who follow social networks and their applications during the week daily, $17.1 \%$ follow them three or four days during the week, $14.6 \%$ follow them for five or more days during the week, while $8.1 \%$ follow them one or more days. Two days during the week. The previous results show that most of the respondents follow social networks and their applications on a daily basis, so that they have become the easiest, fastest and easiest way to use, especially around the deal of the century. Most of the elites are looking for a means that enables them to continuously learn the course of events around the Deal of the Century. This result is consistent with the Abu Salah study ${ }^{20}$, which showed that $74.8 \%$ of the respondents used social networks every day.

- The number of hours of daily follow-up of social networks and their applications:

Table No. (6). Shows the daily rate of follow-up of social networks and their applications

\begin{tabular}{|l|l|l|}
\hline Number of follow-up hours & Repetition & percentage \% \\
\hline two hours to less than three hours & 29 & 29 \\
\hline Three hours or more & 64 & 52.0 \\
\hline an hour to less than two hours & 20 & 16.3 \\
\hline Less than an hour & 10 & 8.1 \\
\hline total & 123 & 100.0 \\
\hline
\end{tabular}

The results of the previous table indicate that $23.6 \%$ follow social networks per day from two hours to less than three hours, $52.0 \%$ follow them per day from three hours or more, $16.3 \%$ follow them per day from one to less than two hours, while a rate of $8.1 \%$ They are the ones who follow social networks for less than an hour a day. The previous results show that most of the respondents follow social networks and their applications every day for a period of up to two to less than three hours. The researcher attributes this to the nature of the political elite, as they want the fastest means to follow up and through the mobile phone that allows them to follow the content of social networks and applications more often due to the nature of the tasks entrusted to them; This result is consistent with the Al-Shahloob study ${ }^{21}$, which showed that $58.8 \%$ use social media networks for two hours or more per day. Consistent with the study of Hisham Skaik ${ }^{22}$, which showed that $34.5 \%$ use social networks from one to less than three hours 
The Dependence of the Palestinian political Elite on Social Media Networks and their applications as a Source of information about the Deal of the Century

Second: dependency on social networks and their applications

Table No. (4). Shows the degree of dependence on monitoring social networks and their applications

\begin{tabular}{|l|l|l|l|l|l|l|l|l|}
\hline $\begin{array}{l}\text { Follow- } \\
\text { up }\end{array}$ & $\begin{array}{l}\text { very } \\
\text { high }\end{array}$ & High & Medium & Low & very low & SMA & $\begin{array}{l}\text { Relative } \\
\text { weight }\end{array}$ & $\begin{array}{l}\text { probability } \\
\text { value }\end{array}$ \\
\hline $\mathrm{K}$ & 74 & 28 & 10 & 8 & 3 & 4.32 & 86.3 & 0.000 \\
\hline & 60.5 & 22.6 & 8.1 & 6.2 & 2.6 & & \\
\hline
\end{tabular}

The arithmetic mean statistically at a significance level of 0.05 .

The results of the previous page indicate that $60.5 \%$ depends on social networks and their applications to a high degree, $8.1 \%$ depends on them with a medium degree, $6.2 \%$ depends on them with a low degree and $2.6 \%$ depends on networks and their applications with a low degree.These results may be realistic and similar to reality due to the nature and privacy of networks and their applications in their ability to compete with and excel traditional media. This result is consistent with Ahmed Hammouda's ${ }^{23}$ study, which showed that the percentage of those who use social networks is $96.1 \%$. The researcher believes that the respondents' dependency on social networks with this high percentage is due to their speed in transmitting urgent news and information.

Reasons for relying on social networks and their applications

Table No. (8). Explains the reasons for relying on social networks

\begin{tabular}{|l|l|l|}
\hline $\begin{array}{l}\text { Reasons for relying on social networks and their applications as an } \\
\text { information resource }\end{array}$ & Repetition & Percentage \\
\hline Get information and news of the Deal of the Century & 98 & 80.2 \\
\hline Its speed in transmitting information and news of the deal without obstacles. & 96 & 78.4 \\
\hline Follow up photos and videos related to the deal of the century & 57 & 46.3 \\
\hline The ability to update information according to the developments of the events & 51 & 41.2 \\
\hline Living with people's pains and worries & 45 & 36.4 \\
\hline It allows interactivity with the information you provide & 38 & 31.2 \\
\hline Smooth handling and ease of use & 36 & 29.3 \\
\hline Follow up on the successive Zionist practices & 32 & 26.1 \\
\hline Daring to address the various issues of the deal of the century & 14 & 11.2 \\
\hline Follow up on the comments of the official Israeli authorities & 13 & 10.6 \\
\hline others & 8 & 6.1 \\
\hline
\end{tabular}

Multiple choice, $n=123$

The results of the previous table show that $80.2 \%$ consider obtaining information and news about the deal of the century as the reason for their reliance on social networks and their applications as a source of information. $78.4 \%$ believe that the reason is its speed in transmitting information and news about the Deal of the Century without obstacles. $46.3 \%$ consider the reason to be following the photos and videos related to the deal; $41.2 \%$ believe that the reason is its ability to update information according to the developments of events; $36.4 \%$ consider the reason to live with people's pain and worries; $31.2 \%$ believe the reason is that it allows interactivity with the information you provide; $29.3 \%$ consider the reason to be easy handling and ease of use; $26.1 \%$ consider the reason to be following the successive Zionist practices; $11.2 \%$ consider the reason to be daring in addressing issues around the various deal of the century; $10.6 \%$ consider the reason to follow-up on the comments of the official Israeli authorities, while $6.1 \%$ consider other groups. This may be due to the speed of networks and their ability to gather opinions and opinions across newsgroups operating across the network space. This is in agreement with Al-Masry's study, which concluded the capabilities of communication networks in providing the elite with information on the Palestinian issue.

2. The most important social networks and their relied upon applications: Table No. (9) illustrates the most important social networks and their relied upon applications

\begin{tabular}{|l|l|l|}
\hline The most important social networks and their applications & repetition & percentage \\
\hline WhatsApp application & 115 & 93.4 \\
\hline Facebook network & 106 & 86.5 \\
\hline
\end{tabular}


The Dependence of the Palestinian political Elite on Social Media Networks and their applications as a Source of information about the Deal of the Century

\begin{tabular}{|l|l|l|}
\hline Twitter network & 80 & 65.3 \\
\hline YouTube network & 41 & 33.6 \\
\hline Telegram application & 26 & 21.2 \\
\hline Instagram application & 11 & 9.1 \\
\hline others & 3 & 2.3 \\
\hline
\end{tabular}

Multiple choice, $n=123$

The results of the previous table show that $93.4 \%$ consider WhatsApp one of the most important applications in social networks that they rely on as a source of information about the Deal of the Century, while $86.5 \%$ consider Facebook; $65.3 \%$ consider them to be a Twittering network; $33.6 \%$ consider the YouTube network; $5.49 \%$ consider the app Telegram; $1.83 \%$ consider blogs and other applications; $21.2 \%$ consider the app Telegram, while 9.1\% consider the Instagram network.It is evident from the previous results that the WhatsApp application ranked first and then Facebook ranked second. This is in agreement with many previous studies such as the Mudhi study ${ }^{24}$, which showed that the Facebook network ranked first with 97.6\%; I disagreed with Ramy Al-Sharafi's study $^{25}$,which showed that Facebook ranked first with $82.11 \%$.The researcher attributes that the WhatsApp application was ranked first due to the piracy that the Facebook network is doing, the removal of Palestinian content and the closing of a large number of pages of Palestinian institutions and political figures under the pretext of terrorism. Content that does not comply with these terms of use; Also in response to the Zionist calls and the pressures on the management of the Elvis network that were practiced by the Zionist lobby groups and the lobbies operating in the American decisionmaking centers

3. The degree of trust in social networks and their applications: Table No. (10) shows the degree of trust in social networks and their applications.

\begin{tabular}{|l|l|l|l|l|l|l|l|l|}
\hline $\begin{array}{l}\text { Follow- } \\
\text { up }\end{array}$ & $\begin{array}{l}\text { very } \\
\text { high }\end{array}$ & High & Medium & Low & $\begin{array}{l}\text { very } \\
\text { low }\end{array}$ & SMA & $\begin{array}{l}\text { Relative } \\
\text { weight }\end{array}$ & $\begin{array}{l}\text { probability } \\
\text { value }\end{array}$ \\
\hline K & 19 & 28 & 51 & 15 & 10 & 3.25 & 65.00 & 0.00 \\
\hline$\%$ & 15.6 & 22.3 & 41.7 & 12.8 & 8.2 & & \\
\hline
\end{tabular}

- The arithmetic mean statistically at a significance level of 0.05

The results of the previous table indicate that $15.6 \%$ of those who have confidence in social networks and their applications as a source of information about the Deal of the Century are very high. While the rate of $22.3 \%$ are of those who have high confidence; A rate of $41.7 \%$ are among those whose confidence level is moderate; A rate of $12.2 \%$ are of those whose confidence level is low; A rate of $8.2 \%$ are among those whose confidence level is very low. In general, it was found that the relative weight is equal to $65.00 \%$, and the probability value is equal to 0.000 , which is less than the significance level 0.05 .This indicates a high approval of the degree of trust in social networks and their applications as a source of information about the Deal of the Century. It is evident from the previous results that the degree of the respondents' confidence in social networks and their applications was moderate. This result is consistent with Ahmed Hammouda's study ${ }^{26}$ which showed that the confidence rate was $69.7 \%$ for males and $66.6 \%$ for females, which shows the average confidence in the contents of social media networks among their audiences. Consistent with Zuhair Abed's study ${ }^{27}$, which showed that users trust social media content by up to $58 \%$. The researcher attributes that social media networks get an average rate because the political elite considers them an indicator for obtaining information, and its content must be checked and confirmed

T1. The cognitive effects resulting from depending on social networks and their applications. To answer this question, a single-sample t-test was used, and the mean, the relative weight, and the probability value were calculated for each paragraph of the field. The results are shown in Table (11). 
The Dependence of the Palestinian political Elite on Social Media Networks and their applications as a Source of information about the Deal of the Century

Table No. (11). The cognitive effects resulting from the respondents' adoption of social networks.

\begin{tabular}{|c|c|c|c|c|c|c|}
\hline $\mathrm{N}$ & Cognitive effects & SMA & $\begin{array}{l}\text { Relative } \\
\text { weight }\end{array}$ & $\begin{array}{l}\text { Test } \\
\text { value(T) }\end{array}$ & $\begin{array}{l}\text { The probability } \\
\text { value(Sig.) }\end{array}$ & Arrangement \\
\hline 1. & $\begin{array}{l}\text { Learn about the nature of the } \\
\text { deal of the century }\end{array}$ & 4.34 & 88.6 & 16.637 & 0.000 & 2 \\
\hline 2. & $\begin{array}{l}\text { Identify the parties that } \\
\text { support and adopt the deal } \\
\text { of the century }\end{array}$ & 4.45 & 89.0 & 19.123 & 0.000 & 1 \\
\hline 3. & $\begin{array}{l}\text { Learn about the stages of the } \\
\text { deal of the centuryand the } \\
\text { opinions of the factions and } \\
\text { political figures about it. }\end{array}$ & 3.89 & 77.6 & 9.051 & 0.000 & \\
\hline 4. & $\begin{array}{l}\text { Knowing the repercussions } \\
\text { of implementing the deal of } \\
\text { the century, and learning } \\
\text { about the consequences of } \\
\text { that }\end{array}$ & 4.10 & 82.0 & 11.863 & 0.000 & 5 \\
\hline 5. & $\begin{array}{l}\text { Identify the dangers of } \\
\text { applying the deal of the } \\
\text { century to the Palestinian } \\
\text { people. }\end{array}$ & 4.02 & 80.4 & 11.972 & 0.000 & 6 \\
\hline 6. & $\begin{array}{l}\text { Learn the speeches of the } \\
\text { occupation leaders and their } \\
\text { repercussions on the deal }\end{array}$ & 3.90 & 78.0 & 9.226 & 0.000 & 9 \\
\hline 7. & $\begin{array}{l}\text { Learn the speeches of the } \\
\text { resistance leaders and their } \\
\text { implications about the deal }\end{array}$ & 4.19 & 83.8 & 15.860 & 0.000 & 3 \\
\hline 8. & $\begin{array}{l}\text { Learn about the Israeli } \\
\text { propaganda methods about } \\
\text { the deal of the century }\end{array}$ & 3.91 & 78.2 & 3.593 & 0.000 & 8 \\
\hline 9. & $\begin{array}{l}\text { Learn about Arab and } \\
\text { international actions towards } \\
\text { the deal of the century }\end{array}$ & 3.78 & 75.6 & 4.576 & 0.000 & 11 \\
\hline 10. & $\begin{array}{l}\text { Learn about the occupation } \\
\text { practices to implement the } \\
\text { terms of the deal of the } \\
\text { century }\end{array}$ & 3.98 & 79.6 & 10.385 & 0.000 & 7 \\
\hline 11. & $\begin{array}{l}\text { Learn about the } \\
\text { developments in the } \\
\text { application of the deal of the } \\
\text { century to the local and } \\
\text { international world }\end{array}$ & 4.11 & 82.2 & 12.667 & 0.000 & 4 \\
\hline \multicolumn{2}{|c|}{$\begin{array}{l}\text { The general attitude of the degree } \\
\text { of cognitive effects }\end{array}$} & 4.07 & 81.4 & 17.004 & 0.000 & \\
\hline
\end{tabular}

The tabular $t$ value at 0.05 significance level and 163 degree of freedom is 1.96 .

The results of the previous table indicate that the general arithmetic mean of the general attitude of the cognitive effects resulting from your reliance on social networks and their applications as a source of information about the Deal of the Century equals 4.07 with a relative weight of $81.4 \%$. The probability value is 0.000 . It is less than the significance level of 0.05 , which indicates that the general trend of cognitive effects resulting from the respondents' dependence on social networks and their applications as a source of information for the Deal of the Century was very large. The results show through the table that the top two paragraphs according to the relative weight:

The paragraph that stipulated "identifying the parties supporting and adopting the deal of the century" ranked first with its relative weight $(89.0 \%)$, indicating that the paragraph had obtained a degree of approval (very large) by the sample members.

The paragraph that says knowing the content of the nature of the deal of the century "was ranked second with relative weight $(88.6 \%)$, indicating that the paragraph had obtained (great) approval from 
The Dependence of the Palestinian political Elite on Social Media Networks and their applications as a Source of information about the Deal of the Century

the sample members. The researcher believes that knowing the content of the nature of the deal of the century and the parties that adopt it leads the cognitive effects of the respondents. This result may be natural, given that the Palestinian political elites have sought, since the announcement of the deal, to know the terms of the deal, its content and the parties adopting it so that it can develop a national strategy to stand before them and develop methods to confront.

2. The emotional effects of depending on social networks and their applications

To answer this question, a t-test was used for one sample and the arithmetic mean, the relative weight, and the probability value were calculated for each paragraph of the field, and the results are shown in Table (12).

Table No. (12), illustrates the emotional effects resulting from depending on social networks and their applications.

\begin{tabular}{|c|c|c|c|c|c|c|}
\hline $\mathrm{N}$ & Affective effects & SMA & $\begin{array}{l}\text { Relative } \\
\text { weight }\end{array}$ & $\begin{array}{l}\text { Test value } \\
\text { (T) }\end{array}$ & $\begin{array}{l}\text { The probability } \\
\text { value(Sig.) }\end{array}$ & Arrangement \\
\hline 1. & $\begin{array}{l}\text { Feeling frustrated and } \\
\text { anxious as a result of the } \\
\text { failure of the international } \\
\text { powers towards the } \\
\text { Palestinian cause }\end{array}$ & 3.72 & 74.4 & 22.955 & 0.000 & 4 \\
\hline 2. & $\begin{array}{l}\text { Complaining and anger at } \\
\text { the US position that denies } \\
\text { Palestinian rights and its } \\
\text { supporters. }\end{array}$ & 4.01 & 80.2 & 27.437 & 0.000 & 2 \\
\hline 3. & $\begin{array}{l}\text { Popular rallying around } \\
\text { Palestinian } \\
\text { preserving them and not } \\
\text { abandoning them }\end{array}$ & 3.98 & 79.6 & 24.871 & 0.000 & 3 \\
\hline 4. & $\begin{array}{l}\text { Feeling of anxiety and fear } \\
\text { for the future of the } \\
\text { Palestinian cause }\end{array}$ & 3.62 & 72.4 & 18.007 & 0.000 & 5 \\
\hline 5 . & $\begin{array}{l}\text { Feeling of frustration and } \\
\text { fear for the future of } \\
\text { resolving the Palestinian } \\
\text { cause }\end{array}$ & 4.11 & 82.2 & 24.969 & 0.000 & 1 \\
\hline 6 . & $\begin{array}{l}\text { Increased feeling of hatred } \\
\text { for the Israeli occupation as } \\
\text { a result of its denial of } \\
\text { Palestinian rights and its } \\
\text { lack of commitment to } \\
\text { international agreements } \\
\text { and resolutions }\end{array}$ & 3.55 & 71.0 & 11.605 & 0.000 & 6 \\
\hline \multicolumn{2}{|c|}{$\begin{array}{l}\text { The general attitude of the degree of } \\
\text { affective influences }\end{array}$} & 3.83 & 76.6 & 28.222 & 0.000 & \\
\hline
\end{tabular}

*The tabular $t$ value at the level of significance 0.05 and the degree of freedom of " 163 " is 1.96

It was found from the table that the general arithmetic mean of the general attitude of emotional influences resulting from your dependence on social networks and their applications as a source of information about the Deal of the Century is equal to 3.83 with a relative weight of $76.6 \%$. The probability value equals 0.000 . It is below the significance level of 0.05 which indicates that the general trend of emotional influences resulting from your dependence on social networks and their applications as a source of information about the Deal of the Century was significant. The results show through the table that the top two paragraphs according to the relative weight are: The paragraph that reads: "Feeling frustration and fear for the future of resolving the Palestinian cause" ranked first with a relative weight $(82.2 \%)$, which indicates that the paragraph obtained a (large) degree of approval by the sample members. The paragraph that stated "complaining" and anger at the American stance that denies Palestinian rights and the parties supporting it "the researcher believes that the deal of the century left a negative feeling among members of the Palestinian society, given that the hopes 
The Dependence of the Palestinian political Elite on Social Media Networks and their applications as a Source of information about the Deal of the Century

placed on the agreements on peace were great, especially with the international stances that encouraged the Palestinian people to enter the path of peaceful solutions as a way to solve the issue and obtain the people's rights. This result is consistent with the study of Hani Marjan ${ }^{28}$, who confirmed that the emotional effects of the respondents to gain information about the refugee issue was an increase in the feeling of hatred for the Israeli entity by $35.3 \%$.

3. Behavioral influences resulting from depending on social networks and their applications.

To answer this question, a t-test was used for one sample and the arithmetic mean and the relative weight and the probability value were calculated for each paragraph of the field. The results are shown in Table (13).

Table No. (13, illustrates the behavioral effects resulting from depending on social networks and their applications

\begin{tabular}{|c|c|c|c|c|c|c|}
\hline $\mathrm{N}$ & Behavioral effects & SMA & $\begin{array}{l}\text { Relative } \\
\text { weight }\end{array}$ & $\begin{array}{l}\text { Test } \\
\text { value }(\mathrm{T})\end{array}$ & $\begin{array}{l}\text { The probability } \\
\text { value(Sig.) }\end{array}$ & Arrangement \\
\hline 1. & $\begin{array}{l}\text { Presenting ideas and information } \\
\text { that reveal the falsehood and } \\
\text { deceit of the terms of the deal of } \\
\text { the century in front of local and } \\
\text { international public opinion }\end{array}$ & 3.60 & 72.0 & 7.705 & 0.000 & 6 \\
\hline 2. & $\begin{array}{l}\text { Providing information that helps } \\
\text { members of society in the } \\
\text { seriousness of implementing the } \\
\text { terms of the deal of the century }\end{array}$ & 3.62 & 72.4 & 7.666 & 0.000 & 5 \\
\hline 3. & $\begin{array}{l}\text { Participating in awareness } \\
\text { activities to educate people not to } \\
\text { deal with Israeli and American } \\
\text { propaganda about the positivity } \\
\text { of the Deal of the Century }\end{array}$ & 3.85 & 77.0 & 11.360 & 0.000 & 3 \\
\hline 4. & $\begin{array}{l}\text { Appearing to various media } \\
\text { outlets to comment and denounce } \\
\text { the terms of the Deal of the } \\
\text { Century }\end{array}$ & 3.52 & 70.4 & 5.771 & 0.000 & 7 \\
\hline 5. & $\begin{array}{l}\text { Participation in conferences and } \\
\text { seminars denouncing the terms of } \\
\text { the Deal of the Century }\end{array}$ & 3.52 & 69.2 & 4.339 & 0.000 & 8 \\
\hline 6. & $\begin{array}{l}\text { Writing publications calling for } \\
\text { unification of ranks, national } \\
\text { unity, and fighting Palestinian } \\
\text { division to confront the deal of } \\
\text { the century }\end{array}$ & 4.11 & 82.2 & 13.605 & 0.000 & 1 \\
\hline 7. & $\begin{array}{l}\text { Publishing news and national and } \\
\text { international activities rejecting } \\
\text { the Deal of the Century }\end{array}$ & 3.89 & 77.8 & 10.627 & 0.000 & 2 \\
\hline 8. & $\begin{array}{l}\text { Dealing with calls via networks, } \\
\text { applications with Arab and } \\
\text { international efforts and } \\
\text { demonstrations opposing the } \\
\text { provisions of the Deal of the } \\
\text { Century }\end{array}$ & 3.76 & 73.4 & 7.951 & 0.000 & 4 \\
\hline 9. & $\begin{array}{l}\text { Participation in the condemnation } \\
\text { marches that emerged as a result } \\
\text { of the announcement of the Deal } \\
\text { of the Century and its provisions }\end{array}$ & 3.15 & 63.0 & .391 & 0.000 & 9 \\
\hline \multicolumn{2}{|r|}{$\begin{array}{l}\text { The general attitude of the degree of } \\
\text { behavioral influences }\end{array}$} & 3.66 & 73.2 & 10.9920 & 0.000 & \\
\hline
\end{tabular}


The Dependence of the Palestinian political Elite on Social Media Networks and their applications as a Source of information about the Deal of the Century

- The tabular $\mathrm{t}$ value at the level of significance 0.05 and the degree of freedom of "163" is 1.96 .

The results of the table show that the general arithmetic mean of the general trend of the behavioral effects resulting from your dependence on social networks and their applications as a source of information about the Deal of the Century is equal to 3.66, with a relative weight of $73.2 \%$ and the probability value equals 0.000 . It is less than the significance level of 0.05 , which indicates that the general attitude of behavioral effects resulting from the dependence of Palestinian political elites on social networks as a source of information about the Deal of the Century was significant. The results show through the table that the top two paragraphs according to relative weight are: Writing publications calling for unification of ranks, national unity and fighting Palestinian division to confront the Deal of the Century, ranked first with a relative weight $(82.2 \%)$, which indicates that the paragraph has obtained a (large) degree of approval by the respondents. The paragraph "spreading news, national and international activities rejecting the Deal of the Century" was ranked second with the relative weight $(77.8 \%)$; which indicates that the paragraph has obtained a (large) degree of approval by the sample members. The researcher sees "writing publications and posts calling for Uniting ranks, national unity and fighting Palestinian division to confront the Deal of the Century. It ranked first and it had the highest behavioral influences. This result is consistent with the study of Maysoon Amir ${ }^{29}$, which emphasized that national unity, ending the division, and unifying the political programs of the various Palestinian factions is a vital requirement and essential for the Palestinians. The researcher believes that the previous result is a natural result, so that efforts are combined in times of crisis. There shall be a detour around the requirements of the national interest,advancing the public interest over the partisan interest.

4. The most important problems facing social networks and their applications

Table No. (14). shows the most important problems faced by social networks and their applications

\begin{tabular}{|l|l|l|}
\hline Important problems & Repetition & Percentage \\
\hline Publishing information without supporting it with official sources & 74 & 60.2 \\
\hline The source of the information is often anonymous & 69 & 56.1 \\
\hline $\begin{array}{l}\text { Lack of awareness required during use due to the absence of professional } \\
\text { controls }\end{array}$ & 66 & 53.6 \\
\hline Lack of media professionals who use networks and applications & 59 & 47.9 \\
\hline $\begin{array}{l}\text { Use networks and their applications as a means of spreading rumors, with or } \\
\text { without intention. }\end{array}$ & 45 & 36.6 \\
\hline $\begin{array}{l}\text { The absence of objectivity during the publication or circulation of } \\
\text { information among the elites }\end{array}$ & 37 & 30.1 \\
\hline $\begin{array}{l}\text { Lack of public trust and confidence in information published in networks } \\
\text { and applications }\end{array}$ & 30 & 24.4 \\
\hline Others & 9 & 7.3 \\
\hline
\end{tabular}

Multiple choice, $n=123$

The results of the previous table indicate that $60.2 \%$ consider publishing information without supporting it with official sources. $56.1 \%$ consider that the most important problems facing social networks and their applications as a source about the Deal of the Century are the anonymity of the source of information in many times. While a rate of $53.6 \%$ consider the absence of the required awareness during use due to the absence of professional controls. $47.9 \%$ consider the lack of media professionals who use networks and applications. 36.6\% consider using networks and their applications as a means of spreading rumors, with or without intent. $30.1 \%$ consider the absence of objectivity during the publication or circulation of information among the elites. $24.4 \%$ consider that the public's credibility and confidence in the information published in networks and applications are weak. $7.3 \%$ believe that there are other problems. It is evident from the previous results that disseminating information without supporting it with official sources is one of the most important disadvantages of social media networks, followed by the anonymity of the sources and the lack of awareness between them. The researcher believes that this result came because of the presence of many activists in networks and applications that were not specialists in the media field, so that they exaggerated and exaggerated the information without being sure of it. This has a negative impact on individuals within society. 
The Dependence of the Palestinian political Elite on Social Media Networks and their applications as a Source of information about the Deal of the Century

5. Proposals for developing social media networks:

Table No. (15). clarifies proposals for developing social networks

\begin{tabular}{|l|l|l|}
\hline Percentage & Repetition & Proposals \\
\hline $\begin{array}{l}\text { Attention to credibility and objectivity during transmission and } \\
\text { publication }\end{array}$ & 106 & 86.1 \\
\hline $\begin{array}{l}\text { Awareness on the part of users of the characteristics and advantages } \\
\text { of networks and their applications }\end{array}$ & 86 & 69.9 \\
\hline Not to publish news and information without sources & 82 & 66.7 \\
\hline $\begin{array}{l}\text { Establishing codes of honor for use and portability of networks and } \\
\text { applications }\end{array}$ & 70 & 56.9 \\
\hline $\begin{array}{l}\text { Read the terms of use and understand the privacy terms for networks } \\
\text { and applications }\end{array}$ & 61 & 49.6 \\
\hline $\begin{array}{l}\text { Disseminating and transmitting the various perspectives of analysts, } \\
\text { experts and specialists on the topics discussed across networks and } \\
\text { applications }\end{array}$ & 51 & 41.5 \\
\hline Others & 10 & 8.1 \\
\hline
\end{tabular}

Multiple choice, $n=123$

The results of the previous table indicate that $86.1 \%$ consider the concern for credibility and objectivity during transmission and publication as proposals for developing social networks and their applicationsto become an effective source of information during crises and important events. While a rate of $69.9 \%$ consider awareness by users of the characteristics and advantages of networks and their applications. $66.7 \%$ considered not to publish news and information without sources. $56.9 \%$ believe that establishing honor codes for use and transfer from networks and applications. $49.6 \%$ consider read the terms of use and understand the privacy terms for networks and applications. $41.5 \%$ consider publishing and transmitting the various views of analysts, experts and specialists on the topics discussed by networks and applications. $8.1 \%$ believe that there are other proposals. It is evident from the previous results that the interest in credibility, accuracy and objectivity came as the first proposals to develop social media networks and their applications in order to become an effective source of information during the multiple Palestinian crises. As it is noticeable that a large number of elites and individuals use networks and applications widely, technological development is accelerating in all aspects of life. So it is important to integrate and keep pace between traditional and new media to make the best use during crises, especially crucial crises such as, the crisis of the Deal of the Century on the Palestinian cause and the Arab and Islamic region in general, because it is clear that the Deal of the Century has regional extensions that appear in succession and in stages.

Second: The most important findings and recommendations. The study found a set of results as follows:

1. The results of the study showed that $60.5 \%$ depend on social networks and their applications while $22.6 \%$ highly depend on it.

2. The study showed that $80.2 \%$ consider obtaining information and news about the Deal of the Century as the reason for their dependence on social networks and their applications as a source of information while $78.4 \%$ believe that the reason is its speed in transmitting information and news about the Deal of the Century without obstacles.

3. The study revealed that $15.6 \%$ of those who have confidence in social networks and their applications as a source of information about the Deal of the Century are very high while $22.3 \%$ are of those whose confidence is high. $41.7 \%$ are of moderate confidence. $12.2 \%$ were of low confidence. $8.2 \%$ are very low

4. The study shows that $93.4 \%$ consider WhatsApp one of the most important applications in social networks that they depend on as a source of information about the Deal of the Century. 86.5\% consider the Facebook network while $65.3 \%$ consider the Twitter network while $33.6 \%$ consider the YouTube network. $21.2 \%$ consider the Telegram application while $1.83 \%$ considers blogs and other applications. 5.49\% consider it. They consider the Instagram application.

5. The order of the types of influences on the study sample - the cognitive effects resulting from the respondents' dependence on social networks and their applications was $81.4 \%$, followed by the 
emotional effects by $76.6 \%$, then the behavioral effects by $73.3 \%$. Previous results indicate that cognitive effects are superior to affective and behavioral effects.

6. The study showed that the general trend of cognitive effects resulting from the political elites' dependence on social networks and their applications as a source of information about the Deal of the Century is equal to 4.07 , with a relative weight of $81.4 \%$. The probability value is equal to 0.000 , which is less than the significance level of 0.05 which indicates that the general trend of cognitive effects resulting from the respondents' dependence on social networks and their applications as a source of information about the Deal of the Century was very large.

7. The articles of cognitive effects came in first with a relative weight $(89.0 \%)$, which indicates that the paragraph had obtained a degree of approval (very large) by the sample members.

8. The highest relative weight for the emotional effects paragraphs "Feeling frustration and fear for the future solution of the Palestinian issue" came first with a relative weight $(82.2 \%)$, indicating that the item had a (large) degree of approval by the sample members.

9. The highest relative weight for the behavioral effects paragraphs "Writing publications calling for unification of ranks and national unity and fighting Palestinian division to confront the Deal of the Century" was ranked first with its relative weight $(82.2 \%)$ which indicates that the paragraph has obtained a (large) degree of approval by respondents.

10. The study showed that the most important problems faced by political elites when they depend on communication networks and their applications are the dissemination of information without support from official sources, at a rate of $60.2 \%$. 56.1\% consider that the most important problems facing social networks and their applications as a source about the Deal of the Century are the anonymity of the source of information in many times. 53.6\% consider the absence of the required awareness during use due to the absence of professional controls.

11. The study showed that the most important proposals recommended by the Palestinian political elites when depending on social networks about the Deal of the Century that $86.1 \%$ consider the interest in credibility and objectivity during transmission and publication among the proposals to develop social networks and their applications so that they become an effective source of information during crises and important eventsWhile a rate of $69.9 \%$ consider awareness by users of the characteristics and features of networks and their applications. $66.7 \%$ considered not to publish news and information without sources. 56.9\% consider establishing honor codes for the use and transfer of networks and applications. $49.6 \%$ consider reading the terms of use and understanding the privacy terms for networks and applications

\section{Study recommendations:}

Through the researchers reviewing the most important findings of the field study, we can develop a set of recommendations and proposals in order to promote social networks and their applications and develop their performance, especially during the critical crises facing the Palestinian people, similar to the Deal of the Century.

1. The interest of users of social media networks and their applications on Palestinian pages to check the accuracy of the information provided through them during crises, especially the Deal of the Century, as a large amount of information is without a source.

2. The necessity to mention the source of the information provided to the public and to avoid providing news and information from anonymous sources, which raises the level of public confidence in social networks and their applications.

3.Giving more attention by those in charge of social networks, applications, and activists to specialized studies and seminars on the Deal to benefit from its results and information.

4. The necessity for researchers to focus on studying social media networks and linking them to issues and areas that would provide benefit and benefit to society, so that the results enable us to reach solutions to societal problems.

5. The necessity of forming a national committee that includes all political sects and colors to follow up and evaluate the information provided through social networks, the extent of its validity, and the detection through it the lies of Israeli propaganda and refuting them. 
The Dependence of the Palestinian political Elite on Social Media Networks and their applications as a Source of information about the Deal of the Century

\section{REFERENCES}

[1] Al-Shalhoub, The extent to which the Saudi public relies on social media for knowledge of community issues: a survey study in Riyadh.

[2] Mudhi, The Academic Elite's Dependence on Social Media to Get News in Crises: A Case Study of the Terrorist Attack on Al-Zuhur Neighborhood in Tikrit on 4/4/2017.

[3] Nassar, Attitudes of the Media Elite Toward the Credibility of News Pages on Social Media.

[4] Sarafandi, Attitudes of the Political and Media Elite Toward the Palestinian Diplomatic Performance 1993-2016: A Field Study

[5] Al-Masry, The elite's use of social media to market the Palestinian cause

[6] Al-Batsh, the political and media elite's assessment of the Palestinian media discourse towards the issue of the Gaza siege: a field study.

[7] Al-Azzam, The dependence of the Jordanian elites on the talk shows on Al-Jazeera as a source of political information: a field study.

[8] (Ognyanova \& Ball-Rokeach. Political efficacy on the internet: A media system dependency approach. Communication and information technologies annual: Politics, participation, and production.

[9] Khalfa, Jordanian university students' reliance on news websites to seek information on political issues: a field study

[10] Abdul Hamid, A Study of the Public in Media Research (p. 232).

[11] Melvin And Rokeach, Theory Of Mass Communication (p224-226)

[12] Alyan and Ghonaim, Curricula and Methods of Scientific Research (p. 43).

[13] Al-Abd, Design and Implementation of Public Opinion and Media Research Polls (p. 353).

[14] Hussein, Media Research, Foundations and Principles (p. 126).

[15] Taya, Research Methods and Writing the Proposed Research Project (pg. 74).

[16] Abdel Hamid, Research Methods in Media Studies (p. 353).

[17] Dolly, Social Research Method's (p252).

[18] Al-Abd and Azmi, The Statistical Method and Its Uses in Public Opinion Research (p. 103).

[19] See Appendix No. (3)

[20] Abu Salah, University students in Gaza governorates use social media networks and achieved gratification. (P. 123)

[21] Al-Shalhoub, The extent to which the Saudi public relies on social media for knowledge of community issues: A study on the city of Riyadh (p. 62).

[22] Skeik, The role of social media networks in educating Palestinian youth about national issues (p. 132).

[23] Al-Shalhoub, The Saudi Public's Dependence on Communication Sites for Knowledge of Community Issues: A Survey Study on the City of Riyadh (p. 67).

[24] Al-Masry, The Elite Use of Social Media in Marketing the Palestinian Cause (p. 122).

[25] Al Mudihi The academic elite's dependence on social media to obtain news in crises.

[26] Al-Sharafi's study, The role of interactive media in shaping political culture among Palestinian youth (p. 113)

[27] Hammouda, The role of social networks in developing the participation of Palestinian youth in societal issues (p. 123).

[28] Abed, The Role of Social Media Networks in Mobilizing Palestinian Public Opinion Toward Social and Political Change (pp. 1388-1428)

[29] Morgan, University students in Gaza governorates rely on websites to gain information about the Palestinian refugee issue (p. 101)

[30] Amir, Palestinian political elites and their impact on national unity (p. 135)

\section{LIST OF REFERENCES}

\section{FIRST: ARAB SOURCES AND REFERENCES}

[1] Abu Shanab, Hussein, Tarban, and Majid. (2008). Palestinian university students rely on new media to obtain information in times of crisis. A study presented to the Fourth Scientific Conference, Cairo: The International Academy of Media Sciences.

[2] Barghouth, Ismail. (2014). The dependence of Palestinian youth on social networks in times of crisis (unpublished master thesis). Institute for Arab Research and Studies, Cairo. 
The Dependence of the Palestinian political Elite on Social Media Networks and their applications as a Source of information about the Deal of the Century

[3] Hussein, Samir. (1995) Media Research, foundations and principles. I 2. Cairo: The World of Books

[4] Hamdi, Muhammad. (2010) Elite uses of electronic journalism and their implications for the readability of paper newspapers (unpublished master thesis). El Hadj Lakhdar University, Batna, Algeria.

[5] Hammouda, Ahmed. (2013). The role of social media networks in developing the participation of Palestinian youth in societal issues (unpublished master thesis). Cairo University, Cairo.

[6] Skeik, Hisham. (2014). The role of social media networks in educating Palestinian youth about national issues (unpublished master thesis). The Islamic University - Gaza, Palestine.

[7] Ash-Sharafi, Rami. (2012). The role of interactive media in shaping political culture among Palestinian youth (unpublished master's thesis). Al-Azhar University - Gaza, Palestine

[8] Tayeh, Sami. (2007). Research methods and writing the proposed research project, (translated by Salwa Ahmed). Cairo: Center for the Development of Studies and Research in Engineering Sciences.

[9] Abed, Zuhair. (2012). The role of social networks in mobilizing Palestinian public opinion towards social and political change, The Journal of Human Sciences, Nablus, 6 (26), 1388-1428.

[10] Abdul Hamid, Muhammad. (2010) An audience study in media research. I 2. Beirut: Dar Al Fikr. The slave, sympathetic and determined, Zaki. (1993) The statistical method and its uses in public opinion research. I 1. Cairo: The Arab Thought House.

[11] 11)Al abbed, Atif. (2002) Design and Implementation of Public Opinion and Media Polls and Research. I 1. Cairo: The Arab Thought House.

[12] Al-Mazzaharah, Manal. (2012) Theories of Communication. I 1. Amman: House of the March for Publishing and Distribution.

[13] Alian, Rabhi and Ghonaim, Othman. (2000) Scientific Research Approaches and Methods. I 1. Amman: Safaa House for Publishing and Distribution.

[14] Amir, Mason. (2012) Palestinian political elites and their impact on national unity (unpublished master's thesis). An-Najah National University - Nablus, Palestine.

[15] Morgan, Hani. (2015) University students in Gaza governorates rely on websites to gain information about the Palestinian refugee issue (unpublished master's thesis). The Islamic University - Gaza, Palestine.

\section{INTERVIEWS:}

[1] Abu Hashish, Hassan. (2015, June 12). Interviewed by: Amin Wafi and Nidal Barbakh.

[2] Abu Saada, Mukhaimar. (2014, October 15). He was met by Amin Wafi and Nidal Barbakh.

[3] Aquarius steed. (2014, October 16). Interviewed by: Amin Wafi and Nidal Barbakh

[4] Rizqa, Youssef. (2014, October 14). Interviewed by: Amin Wafi Nidal Barbakh.

[5] Zaqout, Samir. (2015, June 10). Interviewed by: Amin Wafi Nidal Barbakh

\section{SECOND: FOREIGN SOURCES AND REFERENCES}

[1] Dolly. D (2010) Social Research Method's, (N.J:Englewood cliffs, Prentice, Hall Inca. Ittp://iug.edu.ps/about htm/3/8/2016.

[2] Melanie S. (2009). Framing the Israeli-Palestinian conflict: Astudy of frames used by three American newspapers (unpublished master's thesis). Faculty of the graduate school, University of Missouri, Columbia.

[3] Najjar, A. (2010). Othering the Self: Palestinians Narrating the War on Gaza in the Social Media. Journal of Middle East Media. Vol. 6 (1), 1-30.

Citation: Dr. Amin Mansour Wafi. "The Dependence of the Palestinian political Elite on Social Media Networks and their applications as a Source of information about the Deal of the Century". International Journal of Media, Journalism and Mass Communications (IJMJMC), vol 7, no. 2, 2021, pp. 05-21 doi: http://dx.doi.org/10.20431/2454-9479.0702002.

Copyright: () 2021 Authors. This is an open-access article distributed under the terms of the Creative Commons Attribution License, which permits unrestricted use, distribution, and reproduction in any medium, provided the original author and source are credited. 